Article

\title{
Environmental Impacts Related to Closed Mines in Inner Mongolia
}

\author{
Honglei Liu ${ }^{1,2, *}$, Qiang Wu ${ }^{1,3}$, Jianxin Chen ${ }^{4}$, Mingjun Wang ${ }^{4}$, Di Zhao ${ }^{1}$ and Cheng Duan ${ }^{4}$ \\ 1 School of Geosciences \& Surveying Engineering, China University of Mining and Technology, Beijing 100083, \\ China; wuq@cumtb.edu.cn (Q.W.); dizhao@student.cumtb.edu.cn (D.Z.) \\ 2 North China Engineering Investigation Institute Co., Ltd., Shijiazhuang 050021, China \\ 3 National Engineering Research Center of Coal Mine Water Hazard Controlling, Beijing 100083, China \\ 4 Geological Environment Monitoring Institute of Inner Mongolia Autonomous Region, Hohhot 010020, China; \\ cjx4378@126.com (J.C.); wangmingjun86@outlook.com (M.W.); duancheng0615@gmail.com (C.D.) \\ * Correspondence: liuhonglei@cumtb.edu.cn; Tel.: +86-010-62314681
}

Citation: Liu, H.; Wu, Q.; Chen, J.;

Wang, M.; Zhao, D.; Duan, C.

Environmental Impacts Related to Closed Mines in Inner Mongolia.

Sustainability 2021, 13, 13473.

https://doi.org/10.3390/su132313473

Academic Editor: Rajesh

Kumar Jyothi

Received: 31 October 2021

Accepted: 1 December 2021

Published: 6 December 2021

Publisher's Note: MDPI stays neutral with regard to jurisdictional claims in published maps and institutional affiliations.

\begin{abstract}
Mining activities, while promoting social and economic development, alter the environments and ecosystems of mining areas. Some of the alterations have negative impacts on the environment, while some have positive impacts. By understanding the positive and negative impacts related to closed mines in Inner Mongolia, this research aims to seek advantages of the positive impacts on the environment and reduce the harm of the negative impacts, extending the mining value chain. The paper reviewed four main negative environmental impacts (NEIs) of closed mines and proposed four positive environmental impacts (PEIs) which include ecosystem services, cultural services, land resources and underground space resources, and energy sources and mineral resources. The paper focused on the environmental problems and the PEI utilization of closed mines in Inner Mongolia with 20 representative cases. It carefully studied the Minda Mine which is a good example to combine several PEI utilization objectives. Multiple PEI objectives, as well as the correlations among different objectives, can benefit closed mines ecologically, economically, and socially. In addition, a three-step framework for closed mine revitalization and the factors affecting the compound PEI objectives are mentioned in the paper.
\end{abstract}

Keywords: closed mines revitalization; post-mining land uses; positive environmental impacts; sustainable utilization; mine environment

\section{Introduction}

Economic development cannot be separated from the exploitation and utilization of mineral resources. Since opening up to foreign trade and investment and implementing free-market reforms in 1978, China has been among the world's fastest-growing economies, with real annual GDP growth averaging 9.5\% through 2018 [1,2]. Mineral resources are a key to the rapid development of China's economy and society, where the total output of the mining industry has been increasing continuously for decades [3]. However, driven by China's supply-side structural reform, the mining industry has come under tremendous pressure to improve its social, economic, and environmental performance [4]. According to statistics provided by the Chinese Academy of Engineering, the number of closed mines in China could reach 15,000 by 2030 [5].

Compared to the fanfare associated with active mines, closed mines are accorded little attention. However, the situation has dramatically changed with the wide attention from the public for closed mines revitalization when the awareness of the circular economy has increased all over the world. A mine is closed when the resource is depleted or exhausted, or mining is no longer economically profitable due to the increased cost of extraction or a much lower market price, or the high safety risk of mining-related activities [6]. There are three types of closed mines: abandoned mine, policy-closed mine, and orphaned mine [7]. 
The mine is abandoned due to resource depletion, or widely publicized mining accidents and disasters. Policy-closed mines, located in nature reserves, are forced to close by the local environmental policies and regulations. Orphaned mines are mines where the owner cannot be found or is financially unable to carry out environmental restoration after the mine is closed.

Next to the substantial impacts on local and regional environments in active mines, closed mines are causing major environmental problems in China, which continue to deteriorate land, water bodies, and air. The subsidence area caused by coal mining alone is as high as $2.33 \times 10^{6} \mathrm{hm}^{2}$ and grows at the rate of $2.00 \times 10^{4} \mathrm{hm}^{2}$ per year. Gangue dumps, fly ash, and other solid wastes discharged in the process of coal mining and processing total 4.5 billion tons, which have occupied about $8.00 \times 10^{4} \mathrm{hm}^{2}$ of land [8]. Open-pit mining occupies large farming areas needed for excavation and dumping operations, where the treatment is quite difficult, most even irreversible. Meanwhile, mining-related activities produce a large number of toxic and harmful substances that result in the serious problem of water pollution.

To address the negative environmental concerns of mining, mitigation, and remedial measures are researched on NEI of mining activities, such as acid mine drainage treatment [9], open-pit mining high-steep slope stability prediction [10], and reclamation and rehabilitation of waste dumps [11]. To date, little research has been conducted into PEI or synthesis overview of the systems-level utilization patterns in closed mines. Current research in the reuse of mine land resources has gained increasing attention along with post-mining rehabilitation of the land, such as the land-reusing plans for agriculture, forestry, recreation, construction, conservation, and lakes. Despite landscapes damage in mines, they abound with potential economic values from the natural and cultural heritage, such as the land use for pastures, aquaculture, wildlife habitats, educational, sport and leisure facilities, and industrial uses. Thus, a systematic study of environmental impacts and sustainable utilization of closed mines plays a critical role in extending the mining value chain.

\section{Environmental Impacts Related to Closed Mines}

Mining activities not only significantly influence the environment in the construction and production stages but also continue to interact with the natural environment in the postmining stage even when a mine ceases production and decommissioning is complete [12] The environmental impacts of closed mines can be divided into two types: negative environmental impacts (NEIs) and positive environmental impacts (PEIs) [13]. Briefly, NEIs are the direct and indirect adverse consequences on the natural environment that result from mining activities, such as deforestation, erosion, contamination and alteration of soil profiles, contamination of local streams and wetlands, and an increase in noise levels, dust, and emissions [14,15]. Likewise, PEIs also result from mining (e.g., underground space, land resources, mining heritage), which exists simultaneously with NEI. Both PEI and NEI have been associated with the life-cycle of mining that begins with exploration and continues through production and post-mining.

\subsection{The Negative Environmental Impacts}

The NEIs of mines vary from one site to the other according to mineral species, mining methods, and mineral processing [16]. NEIs in closed mines have resulted in hidden dangers of serious property and casualty losses, which mainly include four types: contaminated groundwater, surface water and groundwater cross strata pollution, secondary collapse, and threats to the surrounding active mines.

\subsubsection{Contaminated Groundwater Source}

Without an operational drainage system in a mine, it will be flooded by surface water and groundwater. In open-pit mines, surface waters come from precipitation and water bodies (e.g., rivers, streams), and groundwater comes from aquifers connected 
to the pit; these waters will flood an open pit and lead to a pit lake. Water in flooded closed underground mines may stabilize or reverse declining water levels in an aquifer, and the groundwater levels at an aquifer of the mining area will gradually increase [17]. The deposits, such as a coalbed that contains iron sulfide $\left(\mathrm{FeS}_{2}\right)$ and other sulfur-bearing minerals, when exposed to oxygen can react to form sulfuric acid $\left(\mathrm{H}_{2} \mathrm{SO}_{4}\right)$ in the presence of humidity, which makes the groundwater strongly acidic. In flooded mines, high amounts of metal ions, even heavy metals, dissolved in groundwater can contribute to or cause adverse health conditions from prolonged exposure that lead to a range of chronic diseases (e.g., cancer and cardiovascular disease). In addition, contaminants, including metal items, wood waste, sludge, and human waste, become the source of pollution in groundwater in closed mines.

\subsubsection{Surface Water and Groundwater Cross Strata Pollution}

As shown in Figure 1, contaminated groundwater impacts the water quality of the upper and lower aquifers through the fissure zone in the mining roof and floor. The fractured roof water-conducting fissure zone and floor disturbance failure zone formed by mining are the primary channels for aquifer recharge, and aquifer storage and recovery in closed mines [18]. In addition, once the groundwater contaminant plume discharges to surface water (e.g., spring, water-conducting wells, faults, or collapse columns), contaminated water will continue to pollute soil and release contaminants into the ecosystem [19].

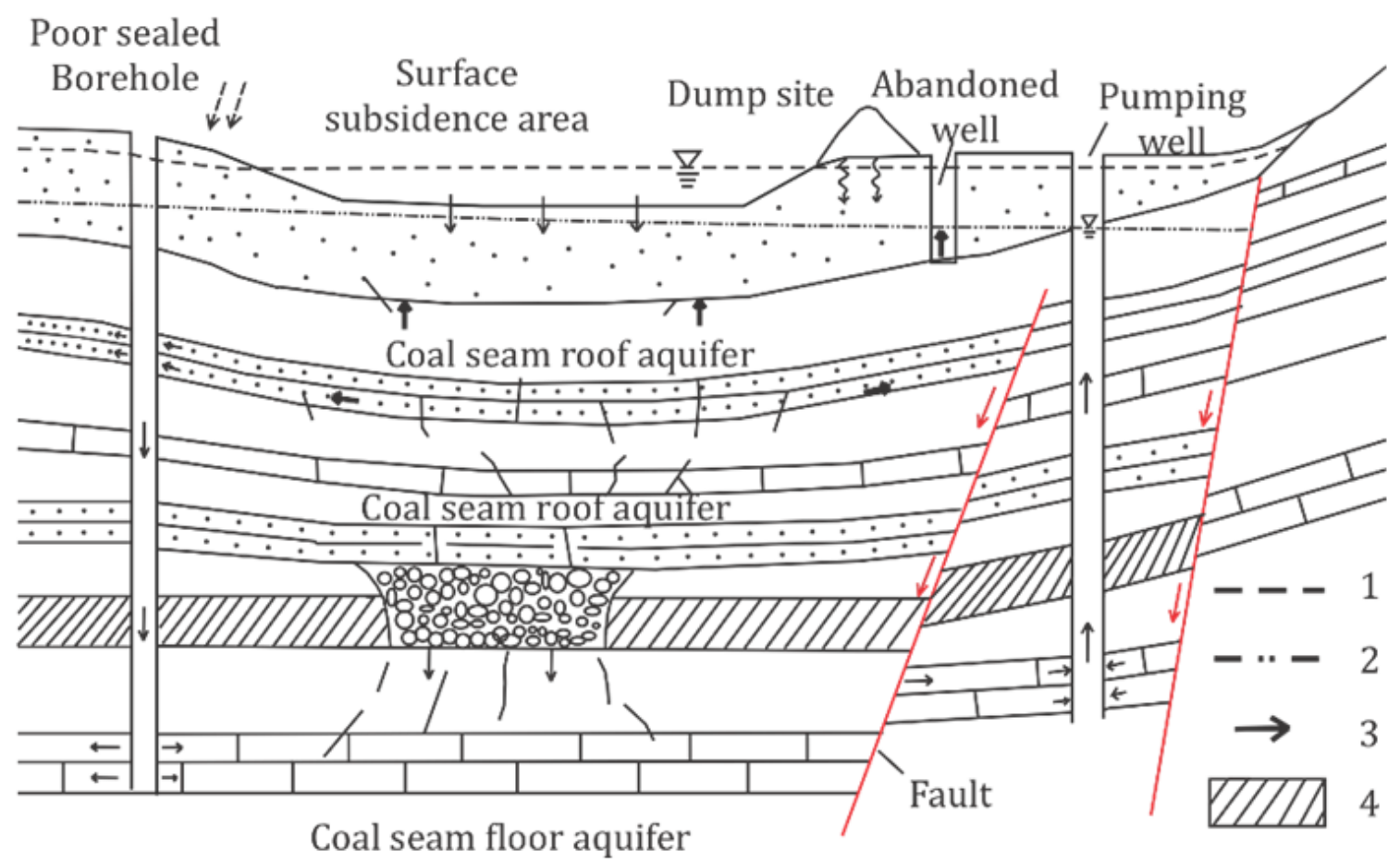

Figure 1. Surface water and groundwater cross strata pollution (adapted from [20]): 1: quaternary groundwater level; 2: rebound groundwater levels of abandoned mine; 3: pathways of the pollutant; 4: coal seam.

\subsubsection{Secondary Ground Collapse}

When a mine gets flooded, coal pillars that are left to support roadway stability and coal seam roof overburden are soaked in water. The shear and compressive strength of coal pillars decrease as soaking time increases. It lowers the roof stability and leads to potential secondary ground collapse which causes geological hazards (e.g., landslides, ground collapse, debris flow). Additionally, faults and ground fissures in the mining area can be activated and lead to significant ground collapse. 


\subsubsection{Threatens to the Surrounding Active Mines}

Flooded closed mines seriously threaten the safety of the surrounding active mines. Once the size of the waterproof coal pillars between mines is inadequate or damaged by mining, the water on the side of high gravitational potential energy will flood all goaf below the elevation of the goaf. Though it will not be completely destroyed, coal pillars' waterproof capacity loss due to disturbance of mining operations results in water accumulation in the goaf of closed mines. It would continuously fill the active mines, which hence decreases drainage effectiveness and increase the production cost for mining.

\subsection{The Positive Environmental Impacts}

The positive environmental impacts put forward in the early 1990s to reuse damaged land and mined underground space and create social-economic and environmental benefits to extend the mining value chain $[21,22]$. To date, the scope of PEI has extended to underground reservoirs; oil, municipal waste, industrial waste storage, and animal husbandry; mine science popularization and industrial tourism; underground in situ scientific experiments; underground pumped-storage hydropower [23]. Four objectives of PEI utilization and the corresponding solutions for post-mining land uses are suggested as shown in Table 1.

Table 1. Objectives of PEI utilization in closed mines.

\begin{tabular}{|c|c|c|c|c|}
\hline No. & Objectives & Sub-Objectives & Solutions & Cases \\
\hline 1 & Ecosystem services & & $\begin{array}{l}\text { Grasslands, artificial forest wetlands, } \\
\text { artificial lakes }\end{array}$ & $\begin{array}{c}\text { La Sal Creek Watershed Project, } \\
\text { Colorado, USA; } \\
\text { Bayhorse Silver Mine recreation } \\
\text { projects, Idaho, USA; Lignite coal } \\
\text { mine reclamation, Lusatia, Germany }\end{array}$ \\
\hline 2 & Cultural services & $\begin{array}{c}\text { Science } \\
\text { popularization } \\
\text { Industrial tourism } \\
\text { Scientific research } \\
\text { sites }\end{array}$ & $\begin{array}{c}\text { Geology science popularization } \\
\text { education base, mine cultural center } \\
\text { Mine park, mining tourism, mines } \\
\text { museum } \\
\text { In situ mining research, underground } \\
\text { scientific experiments, underground } \\
\text { nuclear testing }\end{array}$ & $\begin{array}{c}\text { Bonne Terre Mine, Missouri, USA; Old } \\
\text { Tungsten Mine Park, USA; Britannia } \\
\text { Mine Museum, British; Gran Sasso } \\
\text { National Laboratory, Italy; Sanford } \\
\text { Underground Research Facility, USA; } \\
\text { Sudbury Neutrino Observatory } \\
\text { Lab, Canada }\end{array}$ \\
\hline 3 & $\begin{array}{l}\text { Land resources and } \\
\text { underground space }\end{array}$ & $\begin{array}{l}\text { Underground space } \\
\text { resource }\end{array}$ & $\begin{array}{l}\text { Lands for warehouses, factories, and } \\
\text { industrial properties, mine cemetery, } \\
\text { mine agricultural land (farming, } \\
\text { planting, animal husbandry) } \\
\text { Underground storage, underground } \\
\text { reservoir, underground shelters, } \\
\text { underground farming, hazardous } \\
\text { waste disposal, underground nursing } \\
\text { homes }\end{array}$ & $\begin{array}{l}\text { Zollverein Coal Mine Industrial } \\
\text { Complex, Germany; Lampivaara } \\
\text { Amethyst Mine, Finland; Martelange } \\
\text { Mine, Belgium; Asturian Central Coal } \\
\text { Basin, Spain; Tangshan Coal Mine, } \\
\text { China; Jintan Salt Mine, China; } \\
\text { Tuz Golu Salt Mine, Turkey }\end{array}$ \\
\hline 4 & $\begin{array}{l}\text { Energy sources and } \\
\text { mineral resources }\end{array}$ & $\begin{array}{l}\text { Renewable energy } \\
\text { sources }\end{array}$ & $\begin{array}{c}\text { Low-temperature geothermal, mining } \\
\text { operation water supply } \\
\text { Gas resources, closed mine methane } \\
\text { sucking and power plant, } \\
\text { the photovoltaic power station, } \\
\text { underground pumped-storage } \\
\text { hydropower (UPSH) } \\
\text { Coexisting minerals, lean ore, tailings, } \\
\text { dumps }\end{array}$ & $\begin{array}{l}\text { UPSH at Martelange Slate Mine, } \\
\text { Belgium; } \\
\text { UPSH at Elmhurst Quarry, DuPage } \\
\text { County, USA; Tallings reuse, Gorno, } \\
\text { Italy; Sierra Almagrera Mines, Spain; } \\
\text { Goldcorp Éléonore Mine, Canada; } \\
\text { Robert Müser Mine, Germany }\end{array}$ \\
\hline
\end{tabular}

\subsubsection{Ecosystem Services}

Ecosystem services include not only a wasteland reclamation but also a synthesis of the industrial landscape with modern agriculture, ornamental plants, and animal hus- 
bandry to benefit the surrounding ecosystem of mines, such as grasslands, forest wetlands, and open-pit artificial lakes. It is mainly realized in two ways: artificial restoration and natural recovery. However, natural recovery used to go through a long period without appropriate ecological management or manual guidance when the eco-environment is severely degraded [24]. Besides, animal husbandry activities are of vital ecological functions: for example, processed animal excreta can be utilized as fertilizer for reclamation and protein foods for aquatic plants in artificial lakes or wetlands.

\subsubsection{Cultural Services}

Mining and processing sites can be centers for the popularization of geology and mining sciences, in situ mining, and underground scientific experiments.

(1) Mine cultural and science popularization

Mining and cultural resources are commonly associated with mining activities and facilities, geology and mining engineering, mining history, etc. Mining and geology museum parks in closed mines are one of the effective ways to popularize knowledge of resource protection, energy saving, emissions reduction, and disaster prevention.

(2) Mining tourism

Mining tourism is a niche form of industrial tourism for years. The landscape in abandoned quarries or the post-mining city is a perfect site for people to tour due to the special attractiveness of mine heritage. To date, mining tourism has been developed into a branch of regional tourism or local specialty mining tourism projects all around the world [25].

(3) Underground scientific research sites

Underground space has the advantages of temperature stability (e.g., thermal insulation), isolation (e.g., wind erosion, dust control, acoustic insulation, and vibration damping), and seismic resistance, which is the basic condition for experiments of dark matter. With a great depth, the underground space in mines makes it a suitable location for explosives tests, science tests, and especially the in situ mining tests, which help to improve the technical specifications of mining facilities and adjust their technical parameters.

\subsubsection{Land Resources and Underground Space Resource}

Land that was not affected by mining activities can be used to address the land pressure and shortage of urban land resources, which is compatible with regional land resource planning.

(1) Underground storage space

Underground spaces are potential substitutes to traditional ground storage spaces, which have possible competitive advantages of air defense, explosion-proof, heat insulation, heat preservation, radiation resistance, and cost reduction. It can be divided into different categories according to its end use: strategic material storage, fluid and hazardous gas storage, garbage and solid waste storage, and commodity storage. Besides, the current open pits, horizontal roadways, mine rescue chambers, and central substations can also be used for storage.

(2) Underground water reservoir

The underground water reservoir provides a solution to groundwater conservation, which not only dredges the mine water to the designated goaf for storage and allocation but also substantially reduces evaporation and water loss as in the surface reservoir. The operating cost of storage and allocation for an underground reservoir is lower than that of the surface reservoir [26]. As shown in Figure 2, coal pillars are connected with artificial dams, and the underground reservoir is constructed by using the mined-out space of mines. 


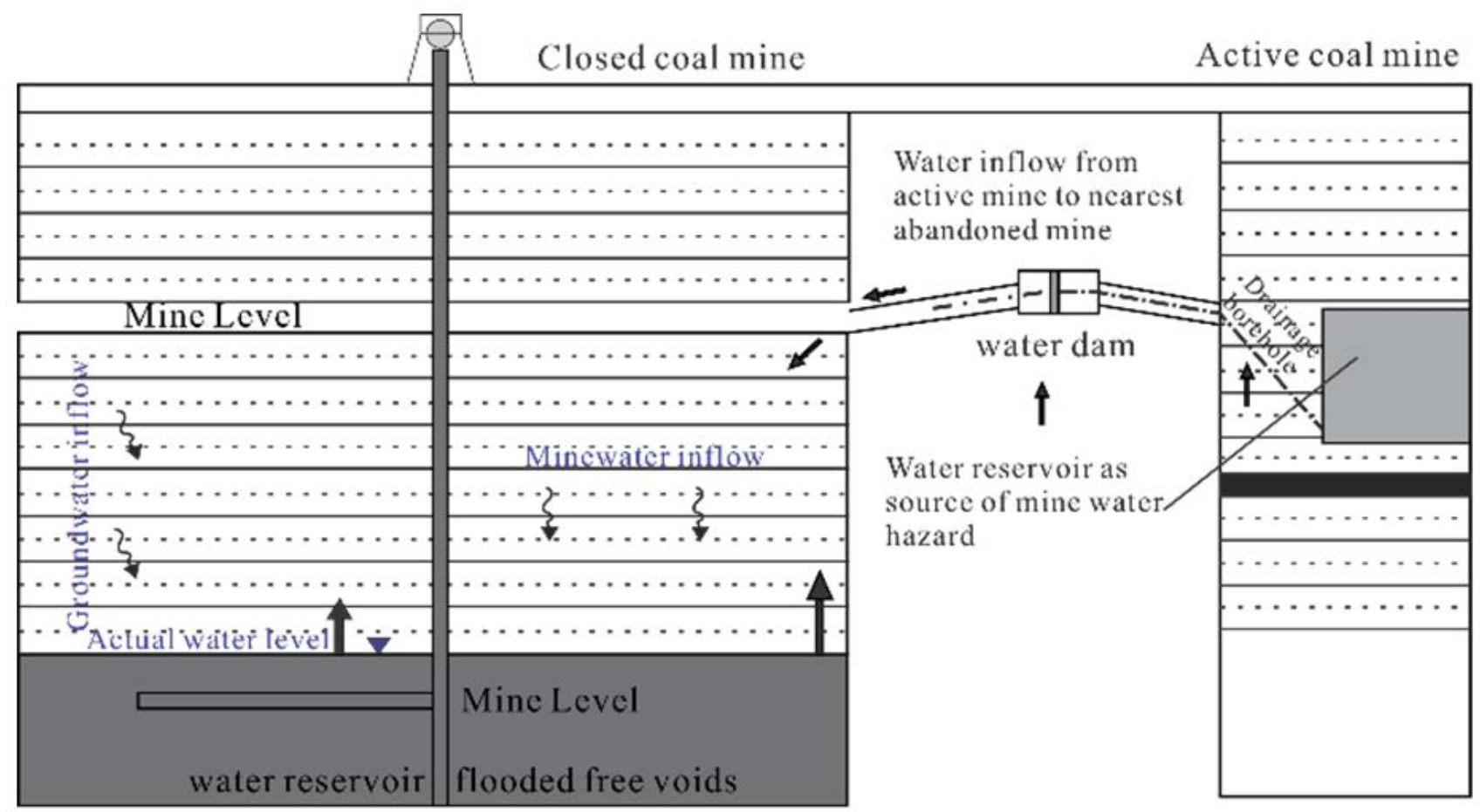

Figure 2. Underground water reservoir in the closed coal mine (adapted from Bukowski et al. 2007 [27]).

(3) Underground cities

The relatively constant environmental temperature and an ideal humidity level render the abandoned underground mine spaces suitable for human access and activities, and become an underground space for living, working, leisure, shopping, and sanatorium. The underground mines and naturally endowed environment can be transformed into an underground civil infrastructure, including underground stations, subways, and tunnels to transit water, utilities, and energy.

\subsubsection{Energy Sources and Mineral Resources}

Coal mine methane resources, mine water resources, hydropower energy resources, photovoltaic power resources, and low-temperature geothermal resources are common resources that can be developed in closed mines.

(1) Coal mine methane

Massive amounts of methane and large quantities of coal that remained in abandoned mines can be redeveloped with the upgrading of mining and processing techniques. Methane from abandoned underground coal mines provides useful on-site power in mining areas by lowering groundwater levels, upgrading pressure-relieving and depressurizing devices, and increasing the number of pressure relief holes on the ground. In addition, coal deposits in closed mines can be gasified to provide synthetic gases for power generation.

(2) Photovoltaic power station

Due to adverse conditions such as rock exposition, land subsidence, poor soil quality, and coal gangue spontaneous combustion, it is difficult to restore such an environment through a reclamation project. But these sites are suitable for photovoltaic power station construction. Solar panels can be installed at slopes in open pits, gangue piles, dumps, tailings, or subsidence areas. In practice, some dumps were developed into dual-use of land for agricultural and solar photovoltaic electricity production (Figure 3a), photovoltaic and pasture-raised farms (Figure 3b), and photovoltaic and fishing grounds (Figure 3c). 


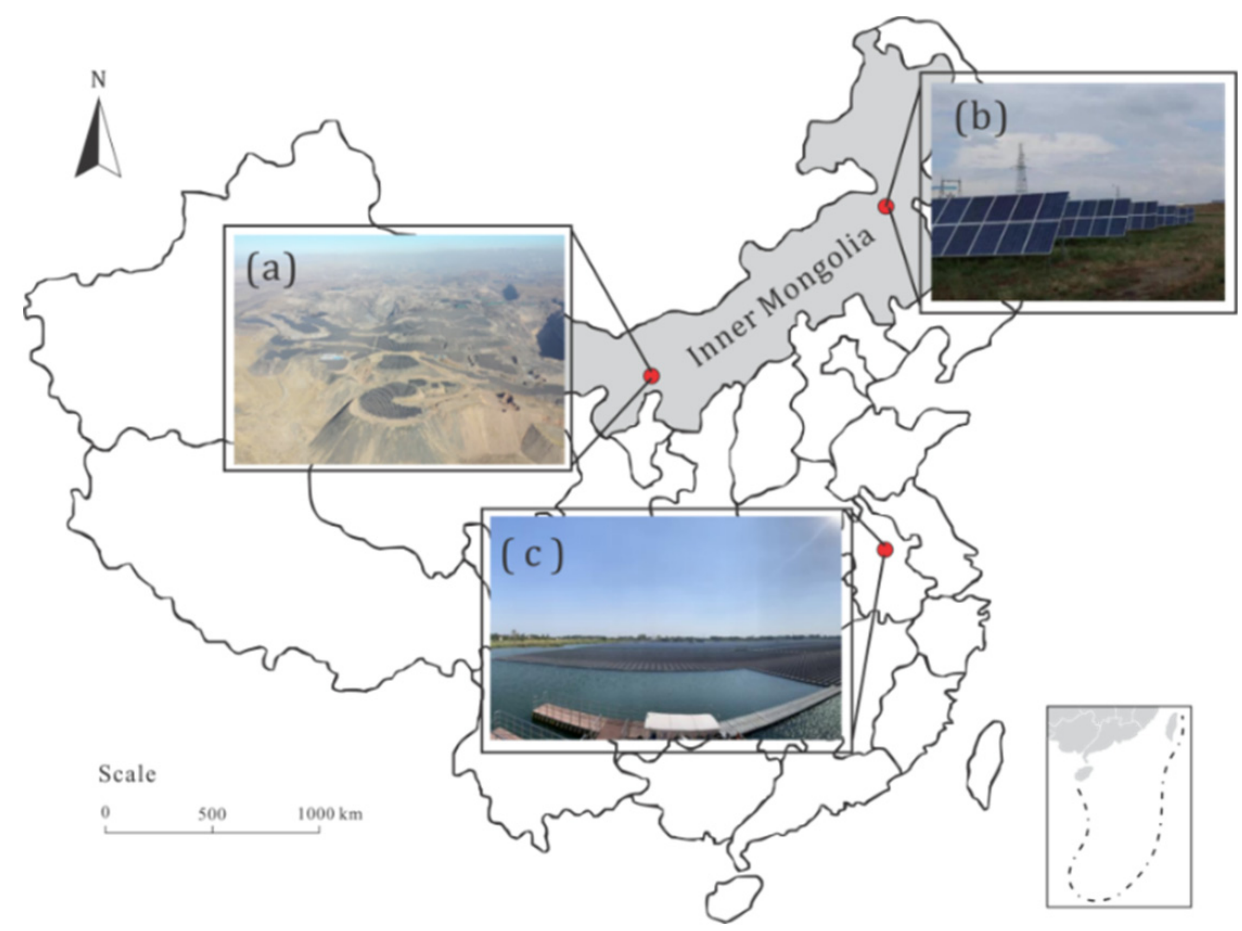

Figure 3. Dual-use of wasteland and photovoltaic power station in closed mines: (a) $50 \mathrm{MW}$ agriculture photovoltaic complementary photovoltaic plant in an abandoned quarry at Wuhai, China; (b) $20 \mathrm{MW}$ photovoltaic power plant and pasture-raised lamb farms at open-pit mine dump, Huolinhe, China; (c) $40 \mathrm{MW}$ floating solar power plants in the subsurface area in Huainan Mine, China.

\section{(3) Mine water resource}

Mine water in closed mines is an alternative water source for drilling, mineral processing, and dust control in active mines [28]. As shown in Figure 4, a mine water utilization system, consisting of a drainage system and water supply system, was established in Fushun West open-pit mine, China. The drainage system is arranged in Quaternary layers, open-pit slope, and pit bottom. In addition, the displacement of the abandoned slope is controlled due to the reduction of groundwater soaking the bottom of the pit as well as mine water drainage and reusing at the pit bottom. Besides, intercepting ditches, diversion channels, rainwater recovery ponds, and drip irrigation sprinkler systems can be built around the mining area to recycle rainwater, mine drainage, and water discharge from human activities as water sources for mining areas, addressing the pollution of surface water bodies and bringing a large amount of water from the city into the mine site.

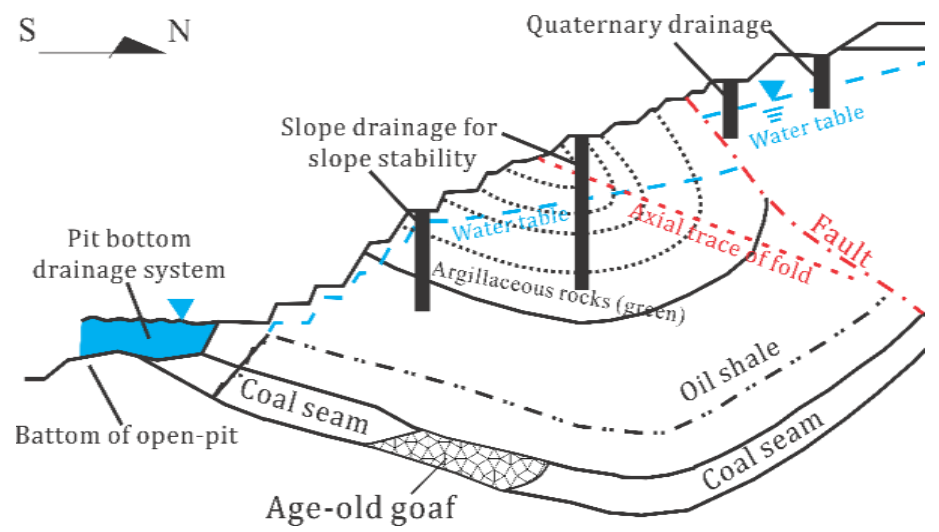

Figure 4. The open-pit drainage system of Fushun West Mine. 
(4) Mine water geothermal energy

The water temperature in the coal mining reservoirs in Europe is usually above $14{ }^{\circ} \mathrm{C}$ [29], which results in enormous quantities of low-temperature heat source water bodies in the mine. Open-loop and closed-loop heat exchanger systems, as shown in Figure $5 \mathrm{a}, \mathrm{b}$, are two methods used in flooded closed mines to extract heat from mine water $[30,31]$. The heat exchanger system consists mainly of a heat pump system and a circulating system. The difference is that the open-loop system utilizes the entire flooded mine as the subsurface heat exchanger, while the closed-loop system utilizes the vertical borehole to extract the heat either in the goaves or aquifers.

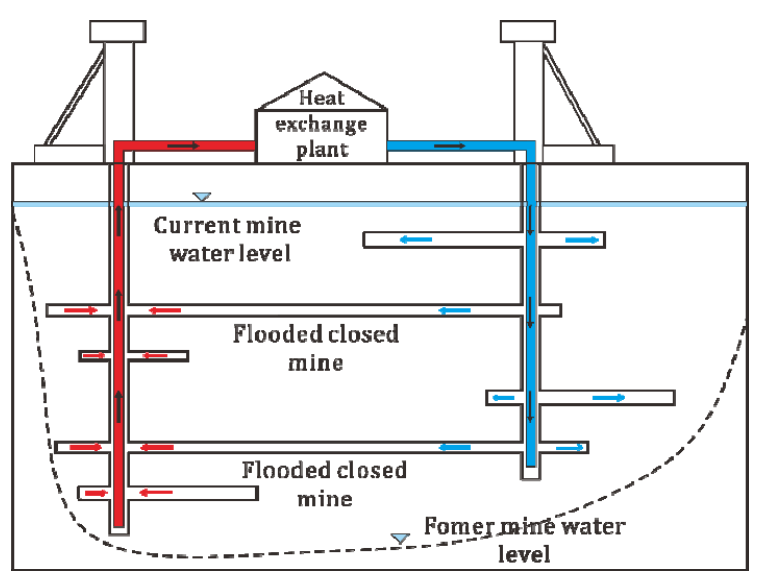

(a)

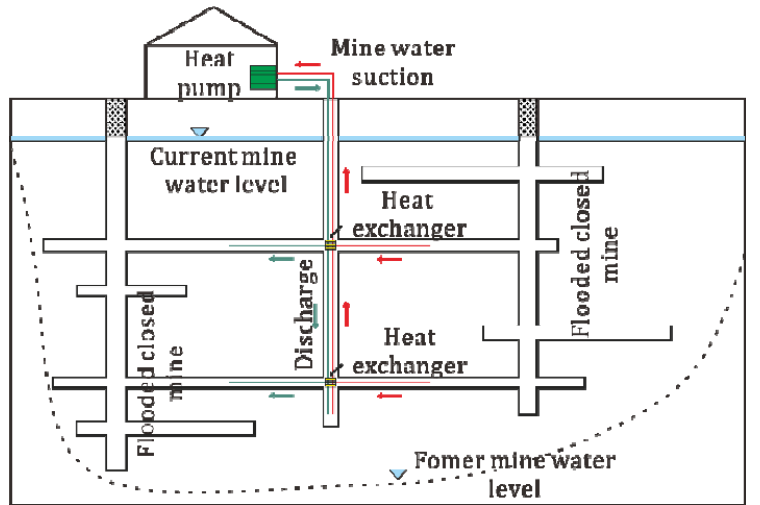

(b)

Figure 5. Schematic of low-temperature geothermal energy in closed mines: (a) open-loop mine water heat exchanger system, (b) closed-loop mine water heat exchanger system.

(5) Underground pumped-storage hydroelectricity

Pumped-storage hydroelectricity serves the function of reducing the peak-valley difference of the power system and improving the load factor and operation [32]. However, the construction of pumped-storage hydroelectricity is limited by topography, lithology, and structure. Some closed mines not only have a huge mine-out space, but also a large mining depth. The pumped-storage hydroelectricity that is constructed in the underground mine can use the goaf, draft, and incline shaft to pump and store water. By transforming the underground space into storage space and building underground hydroelectricity utilities, the deep underground mines can be reused to store the excess of electricity produced during low-demand energy periods and provide power for peak demand on the electrical grid [33].

\section{Closed Mines and Post-Mining Land Use in Inner Mongolia}

\subsection{Closed Mines in Inner Mongolia}

Inner Mongolia borders the north of Mongolia and Russia in North China with an area of 1.18 million square kilometers. With a temperate continental monsoonal climate, it has a cold, long winter with frequent blizzards and a warm, short summer where precipitation is scarce in most regions. The ecological environment is extremely fragile and prone to degradation. Most of Inner Mongolia is arid, semi-arid, and semi-humid from west to east. It has a mean annual temperature of $-1{ }^{\circ} \mathrm{C}$ to $15^{\circ} \mathrm{C}$, and the mean annual precipitation ranges from 100 to $500 \mathrm{~mm}$.

Inner Mongolia has rich deposits of coal, rare earth elements, copper, zinc, lead, etc. Mining is a major industry in Inner Mongolia, which has identified total coal resources of 1.02 trillion tons that account for $26.1 \%$ of the total amount in the country [34]. In 2017, Inner Mongolia produced 850 million tons of coal a year, making up a quarter of China's total output. According to an environmental survey of Inner Mongolia in 2017 from the Geological Environment Monitoring Institute of Inner Mongolia Autonomous Region, 
as shown in Figure 6, the total area of occupied and damaged lands by closed mines is estimated at $399.52 \mathrm{~km}^{2}$, with the solid waste accumulation of about 421.45 million tons.

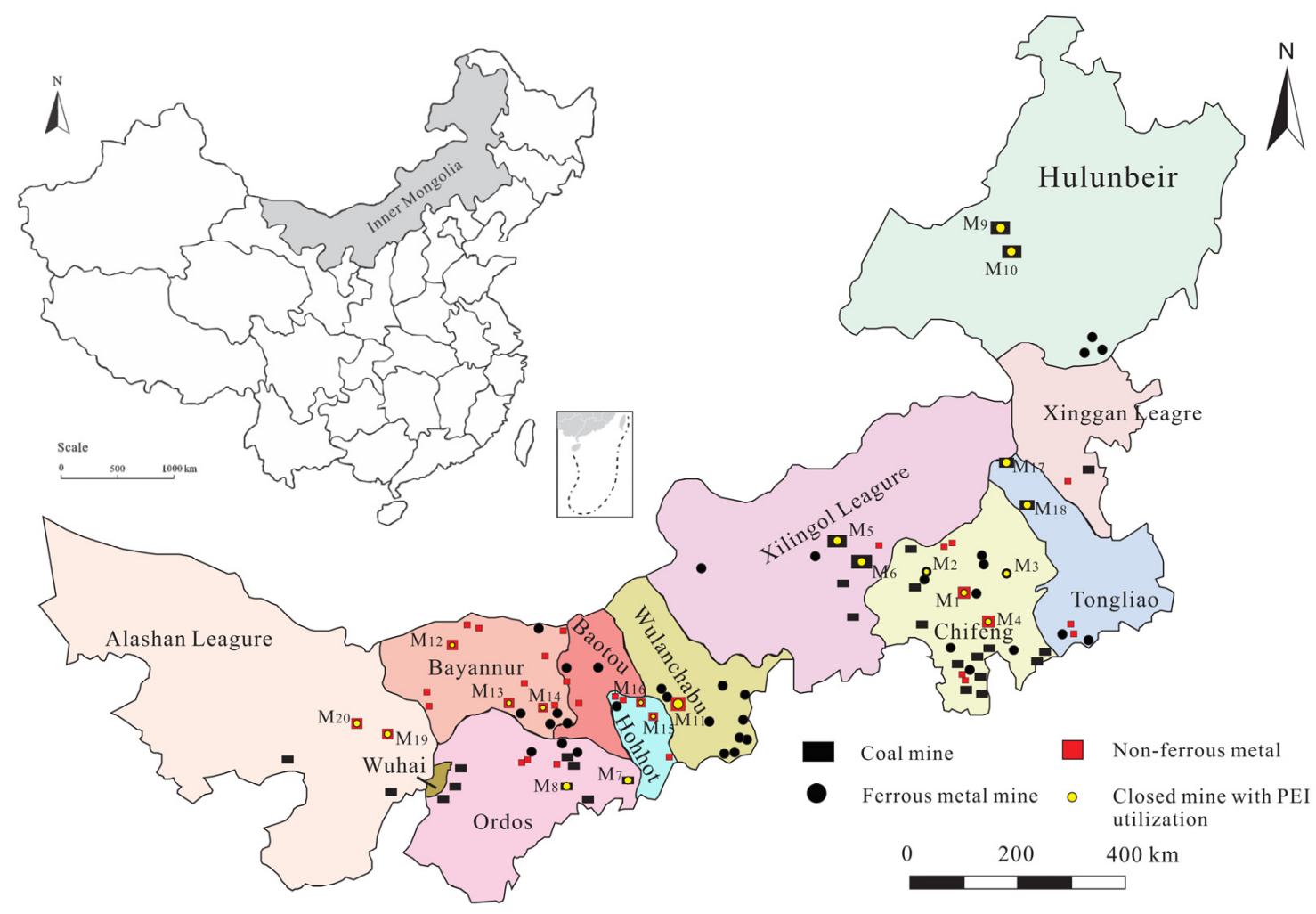

Figure 6. Closed mines in Inner Mongolia, China. The closed mines are listed as $\mathrm{M}_{1}$ : Dajing Copper Mine; $\mathrm{M}_{2}$ : Huang Gang Liang Iron Mine; $\mathrm{M}_{3}$ : Chabuga Clay Mine; $\mathrm{M}_{4}$ : Ongniud Clay Mine; $\mathrm{M}_{5}$ : Shengli No:1 Open-Pit Mine; $\mathrm{M}_{6}$ : Policy-closed mines in Xilinhaote Preserve Area; $\mathrm{M}_{7}$ : Sanjigou Coal Mine; $\mathrm{M}_{8}$ : Minda Coal Mine; $\mathrm{M}_{9}$ : Shenhua Baorixile Surface Mine; $\mathrm{M}_{10}$ : Dayan Coal Mine; $\mathrm{M}_{11}$ : Jinpeng Gold Mine; $\mathrm{M}_{12}$ : Dongshengmiao Pyrite-polymetallic Mine; $\mathrm{M}_{13}$ : South Guodao abandoned quarry; $\mathrm{M}_{14}$ : Shujigou Iron Mine; $\mathrm{M}_{15}$ : Luojiaying abandoned quarry; $\mathrm{M}_{16}$ : Haoqinying abandoned quarry; $\mathrm{M}_{17}$ : Huolinhe Open-Pit Mine; $\mathrm{M}_{18}$ : Lianhe Tun Mine; $\mathrm{M}_{19}$ : Hetongchi Lake Salt Mine; $\mathrm{M}_{20}$ : Jura Gold Mine.

Figure 7 shows the number of closed mines in cities and leagues of Inner Mongolia. Among the 2024 closed mines, 1890 were open-pit mines, accounting for $93.4 \%$ of the total amount. Besides, 127 were underground mines and 7 were mines that combined open-pit and underground mining. Additionally, 1725 closed mines that produced non-metallic minerals account for $85.2 \%$ of the total number of closed mines. In these closed mines, solid waste not only occupied large areas of cultivated land but also is the main source of debris flow in the rainy season and dust storms. The proportion of amount, area, and solid waste mass of closed mines in cities and leagues of Inner Mongolia is shown in Figure 8. There were 1908 mining waste dumps in Inner Mongolia, the total waste accumulation amounts to 255.4 million tons. The amount of waste-rock stockpiles is 1842 , with a total accumulation of 241.7 million tons that accounts for over $94.2 \%$ of the total solid waste [34]. 


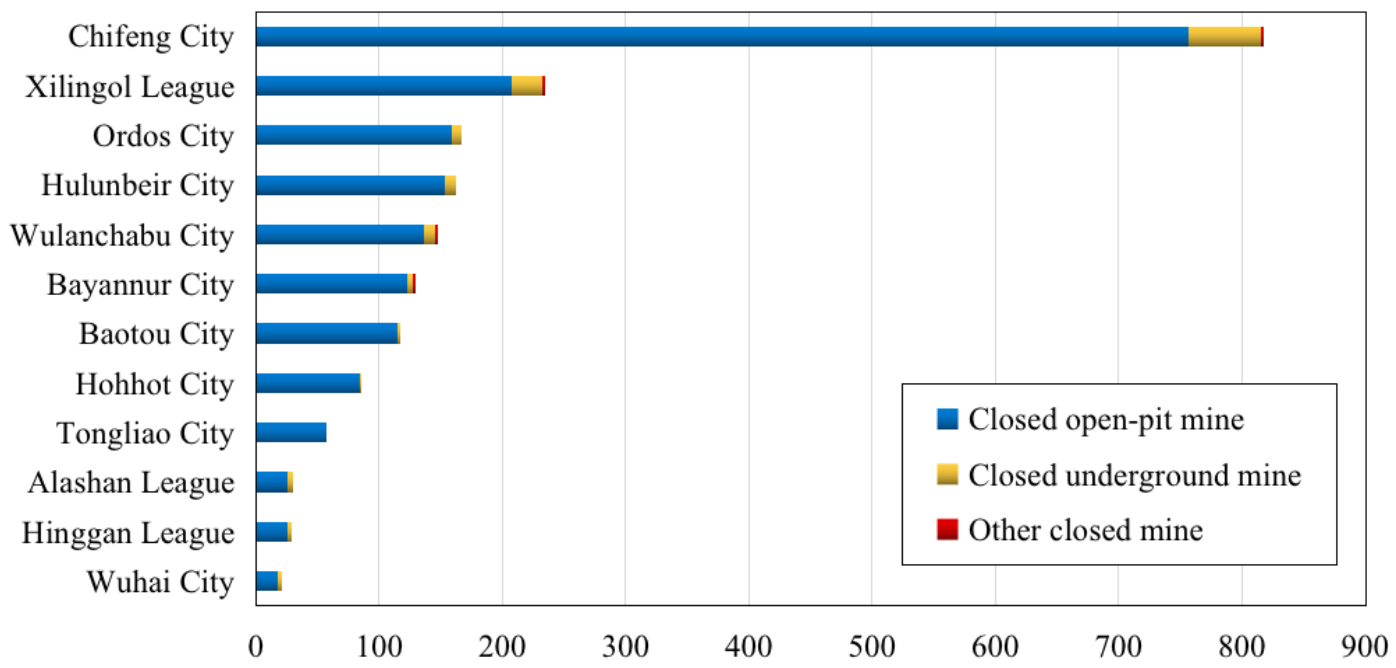

Figure 7. Amount of closed mines in leagues and cities of Inner Mongolia.

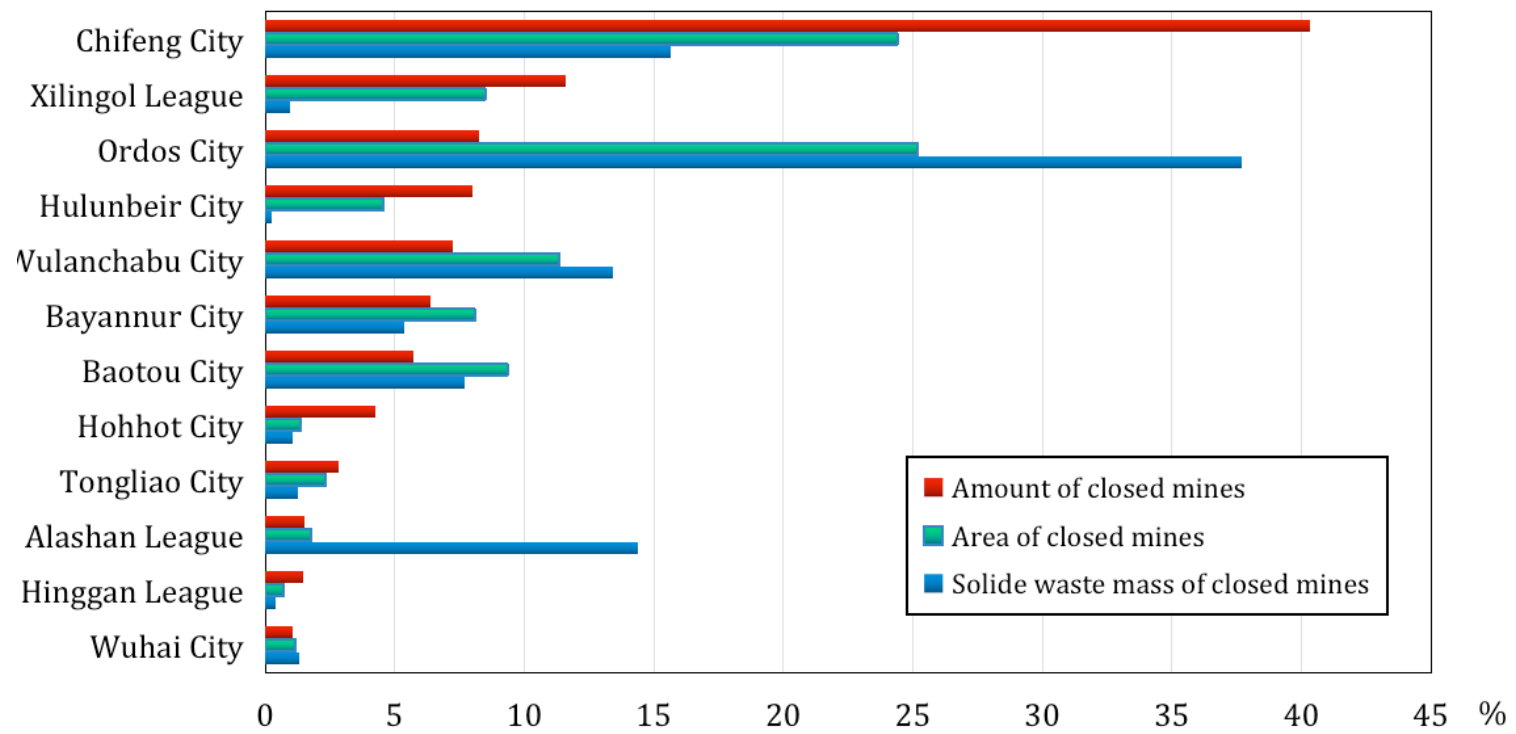

Figure 8. The proportion of amount, area, and solid waste of closed mines in Inner Mongolia.

Inner Mongolia is facing the closure of 2024 mines, damaging $489.6 \mathrm{~km}^{2}$, and there is a significant demand for the revitalization of closed mines by using land resources for development. The paper selected twenty closed mines with various post-mining land-use projects, as given in Table 2, to represent the different locations, geological environmental backgrounds, and mining methods in Inner Mongolia. Among them, both open-pit mines and underground mines are included. Coal mines, as well as non-coal mines from eastern to western Inner Mongolia, are considered, and some of them had completed the revitalization project [34]. 
Table 2. PEI utilization of closed mines in Inner Mongolia.

\begin{tabular}{|c|c|c|c|c|c|c|}
\hline No. & $\begin{array}{l}\text { Area } \\
\left(\mathrm{km}^{2}\right)\end{array}$ & $\begin{array}{l}\text { Mineral } \\
\text { Types }\end{array}$ & $\begin{array}{l}\text { Mining } \\
\text { Methods }\end{array}$ & $\begin{array}{l}\text { Reuse Area } \\
\qquad\left(\mathrm{km}^{2}\right)\end{array}$ & $\begin{array}{l}\text { Investment } \\
(\times C N Y 106)\end{array}$ & Post-Mining Land-Use Projects \\
\hline $\mathrm{M}_{1}$ & 8.01 & Copper & UG & 8.01 & 146.20 & Dajing National Mine Park \\
\hline $\mathrm{M}_{2}$ & 17.17 & Iron & UG & 1.61 & 470.00 & Underground storage space \\
\hline $\mathrm{M}_{3}$ & 4.31 & Limestone & $\mathrm{OP}$ & 4.31 & 1207.80 & $\begin{array}{l}\text { Abandoned mine reclamation (completed } \\
\text { in 2020) }\end{array}$ \\
\hline $\mathrm{M}_{4}$ & 0.83 & Clay & $\mathrm{OP}$ & 0.83 & 343.80 & $\begin{array}{l}\text { Abandoned mine reclamation and } \\
\text { wasteland utilization (completed in 2020) }\end{array}$ \\
\hline $\mathrm{M}_{5}$ & 34.36 & Coal & $\mathrm{OP}$ & 8.64 & 967.60 & Photovoltaic power station on dumps \\
\hline $\mathrm{M}_{6}$ & 5.56 & Limestone & $\mathrm{OP}$ & 5.56 & 906.80 & $\begin{array}{l}\text { Abandoned mine reclamation and } \\
\text { recreation center projects }\end{array}$ \\
\hline $\mathrm{M}_{7}$ & 49.82 & Coal & UG & 8.95 & 560.00 & $\begin{array}{l}\text { Underground mine water reuse projects } \\
\qquad \text { (completed) }\end{array}$ \\
\hline $\mathrm{M}_{8}$ & 20.71 & Coal & $\mathrm{OP}$ & 1.07 & 456.70 & $\begin{array}{l}\text { Underground storage space, } \\
\text { water-resource utilization, and ecosystem } \\
\text { services projects (completed in 2020) }\end{array}$ \\
\hline $\mathrm{M}_{9}$ & 51.64 & Coal & $\mathrm{OP}$ & 3.86 & 150.00 & $\begin{array}{l}\text { Baorixile abandoned mine area } \\
\text { reclamation project (completed in 2013) }\end{array}$ \\
\hline $\mathrm{M}_{10}$ & 28.54 & Coal & UG & 2.25 & 162.60 & $\begin{array}{c}\text { Dayan 2\# abandoned mine reclamation } \\
\text { project (completed in 2017) }\end{array}$ \\
\hline $\mathrm{M}_{11}$ & 2.62 & Gold & $\mathrm{OP}$ & 2.62 & 160.00 & $\begin{array}{c}\text { Abandoned mine reclamation project } \\
\text { (partially completed) }\end{array}$ \\
\hline $\mathrm{M}_{12}$ & 1.39 & Iron & UG & 1.04 & 216.90 & $\begin{array}{l}\text { Underground storage space development } \\
\text { project }\end{array}$ \\
\hline $\mathrm{M}_{13}$ & 0.48 & Sand & OP & 0.48 & 100.00 & Interstate Highway Mine park project \\
\hline $\mathrm{M}_{14}$ & 1.74 & Iron & UG & 0.31 & 24.80 & $\begin{array}{l}\text { The abandoned mine reclamation project } \\
\text { (partially completed) }\end{array}$ \\
\hline $\mathrm{M}_{15}$ & 0.17 & Sand & $\mathrm{OP}$ & 0.17 & 150.00 & $\begin{array}{l}\text { Part of the central campus of a university } \\
\text { (completed in 2017) }\end{array}$ \\
\hline $\mathrm{M}_{16}$ & 0.22 & Sand & $\mathrm{OP}$ & 0.22 & 30.00 & Sand Pit Park (completed in 2016) \\
\hline $\mathrm{M}_{17}$ & 33.99 & Coal & $\mathrm{OP}$ & 0.15 & 47.00 & $\begin{array}{l}\text { Dual-use land for photovoltaic and } \\
\text { pasture-raised farms (completed in 2018) }\end{array}$ \\
\hline $\mathrm{M}_{18}$ & 0.04 & Coal & UG & 0.04 & 30.00 & $\begin{array}{l}\text { Lianhe Tun mine reclamation project } \\
\text { (completed in 2011) }\end{array}$ \\
\hline $\mathrm{M}_{19}$ & 13.82 & Glauber salt & OP & 0.39 & 22.50 & The abandoned mine reclamation project \\
\hline $\mathrm{M}_{20}$ & 0.19 & Gold & OP & 1.01 & 303.70 & Mine park (partially completed) \\
\hline
\end{tabular}

UG: underground mining; OP: open-pit mining.

In Table 2, we can see that 10 of 20 mines were revitalized or aims to revitalize in terms of ecosystem services $\left(\mathrm{M}_{3}, \mathrm{M}_{4}, \mathrm{M}_{6}, \mathrm{M}_{8}, \mathrm{M}_{9}, \mathrm{M}_{10}, \mathrm{M}_{11}, \mathrm{M}_{14} \mathrm{M}_{18}\right.$, and $\left.\mathrm{M}_{19}\right), 6$ of them in terms of cultural services $\left(\mathrm{M}_{1}, \mathrm{M}_{6}, \mathrm{M}_{13}, \mathrm{M}_{15}, \mathrm{M}_{16}\right.$, and $\left.\mathrm{M}_{20}\right), 5$ of them used land resources or underground space $\left(\mathrm{M}_{2}, \mathrm{M}_{8}, \mathrm{M}_{12}, \mathrm{M}_{15}\right.$, and $\left.\mathrm{M}_{17}\right)$, and 4 of them applied the renewable energy sources or water resources $\left(\mathrm{M}_{5}, \mathrm{M}_{7}, \mathrm{M}_{8}\right.$, and $\left.\mathrm{M}_{17}\right)$. Some closed mines applied multiple objectives, rather than a single objective, to maximize the land-using effects, such as $\mathrm{M}_{6}, \mathrm{M}_{8}$, and $\mathrm{M}_{17}$.

By observing the data, we can find that the objective of ecosystem services for closed mines in Inner Mongolia has a high correlation with the location and topographic and geomorphological conditions of the mines. The ecosystem services objective is more successfully reached in mines of the eastern and central regions of Inner Mongolia (e.g., Xilingol League and Hulunbeir City) than in those of the western region (e.g., Bayanmur City and Alashan League) because of heavier precipitation in the eastern and central regions. In addition, the achievement of ecosystem services was related to the mining methods. By comparing the open-pit mines of $\mathrm{M}_{3}, \mathrm{M}_{6}$, and $\mathrm{M}_{19}$ with underground mines of $\mathrm{M}_{18}$, it shows that ecological service objective is more suitable to underground closed mine revitalization than open-pit mine, which is related to both regional natural conditions and mining methods. For the objective of cultural services and land resources and underground 
space in closed mines such as $\mathrm{M}_{1}, \mathrm{M}_{2}$, and $\mathrm{M}_{8}$, it shows that both open-pit mines and underground mines are suitable for underground storage space, geology museums, mine parks, and artificial wasteland. In addition, renewable energy sources have been developed and utilized in four closed mines of Inner Mongolia in reusing water resources, developing underground water reservoirs, and building photovoltaic power generations which have the potential to be widely developed due to Inner Mongolia's average long sunshine hours, which is above $2700 \mathrm{~h}$.

\subsection{Framework for Closed Mine Revitalization in Inner Mongolia}

To adopt suitable PEI objectives and solutions for closed mines in Inner Mongolia, the paper proposes a framework for closed mine revitalization which includes three steps:

(1) NEI survey and treatment

Before conducting PEI utilization, a detailed NEI survey of the closed mine is needed to identify the existed environmental problems, the occurrence and damage mechanics of NEI, and restoration difficulty, providing basic support for the development plan of closed mines. For example, in utilizing the underground mines as the storage sites for municipal waste, solid waste, industrial wastewater, and toxic and harmful gases, the data of closed mines like strata, lithology, structure, and groundwater recharge and discharge, to assess environmental safety risk is needed.

(2) Social and economic background analysis

By analyzing the social and economic background, we can learn the local economic development level, industrial structure, historical and cultural deposits, ensuring that the governance revitalization of closed mines is consistent with the local economic and social development and bringing the dual environmental and economic benefits to the residents of the mining area.

(3) Determination of the objectives and solutions for PEI utilization

Select feasible PEI utilization objectives from the subtypes of PEI, comprehensively consider the current ecological environment in land use, geographical conditions, geological conditions, economic conditions of the mine, expected benefits, and other factors, and combine the actual conditions of the mine and the public's wishes to formulate the closure of the mine PEI revitalization plan.

\subsection{Case Study in Minda Mine $\left(M_{8}\right)$, Inner Mongolia}

Minda Mine $\left(\mathrm{M}_{8}\right)$ is an open-pit coal mine located in Ordos City, Inner Mongolia, with an area of 20.7 square kilometers, mainly producing high-quality thermal coal with low ash and low sulfur, and supplying coal resources for surrounding power plants. Minda coal mine is characterized by a typical erosive hilly terrain with long gullies and valleys. The terrain is generally high in the south and low in the north, high in the west and low in the east, with a maximum height difference of $138 \mathrm{~m}$. The climate is dry, with strong sunlight radiation, abundant sunshine, and a large temperature difference between day and night, which is a semi-arid plateau continental climate. The maximum temperature is $36.6{ }^{\circ} \mathrm{C}$ and the minimum temperature is $-29.6{ }^{\circ} \mathrm{C}$. The average annual precipitation is $350 \mathrm{~mm}$, and it is mostly concentrated in July, August, and September, and the average annual evaporation is $2297.4-2833.7 \mathrm{~mm}$. The wind is strong in spring and winter with a maximum wind speed of $24 \mathrm{~m} / \mathrm{s}$.

Before utilizing PEI, the NEI of Minda Mine was investigated and treated, such as unstable dump slope, soil erosion, and the lacking of surface soil.

Minda Mine is less than $10 \mathrm{~km}$ away from Ordos City, which is a big city with a population of 2,153,638 (2020 census). Due to its location advantage to Ordos City, the land of the dump in Minda Mine, as shown in Figures 9 and A1, was used to develop planting and animal husbandry, providing fresh vegetables, fruits, meat, eggs, and dairy produce for Ordos. Trees planted in the dumping field can prevent wind and sand, strengthen the fragile ecological environment. 


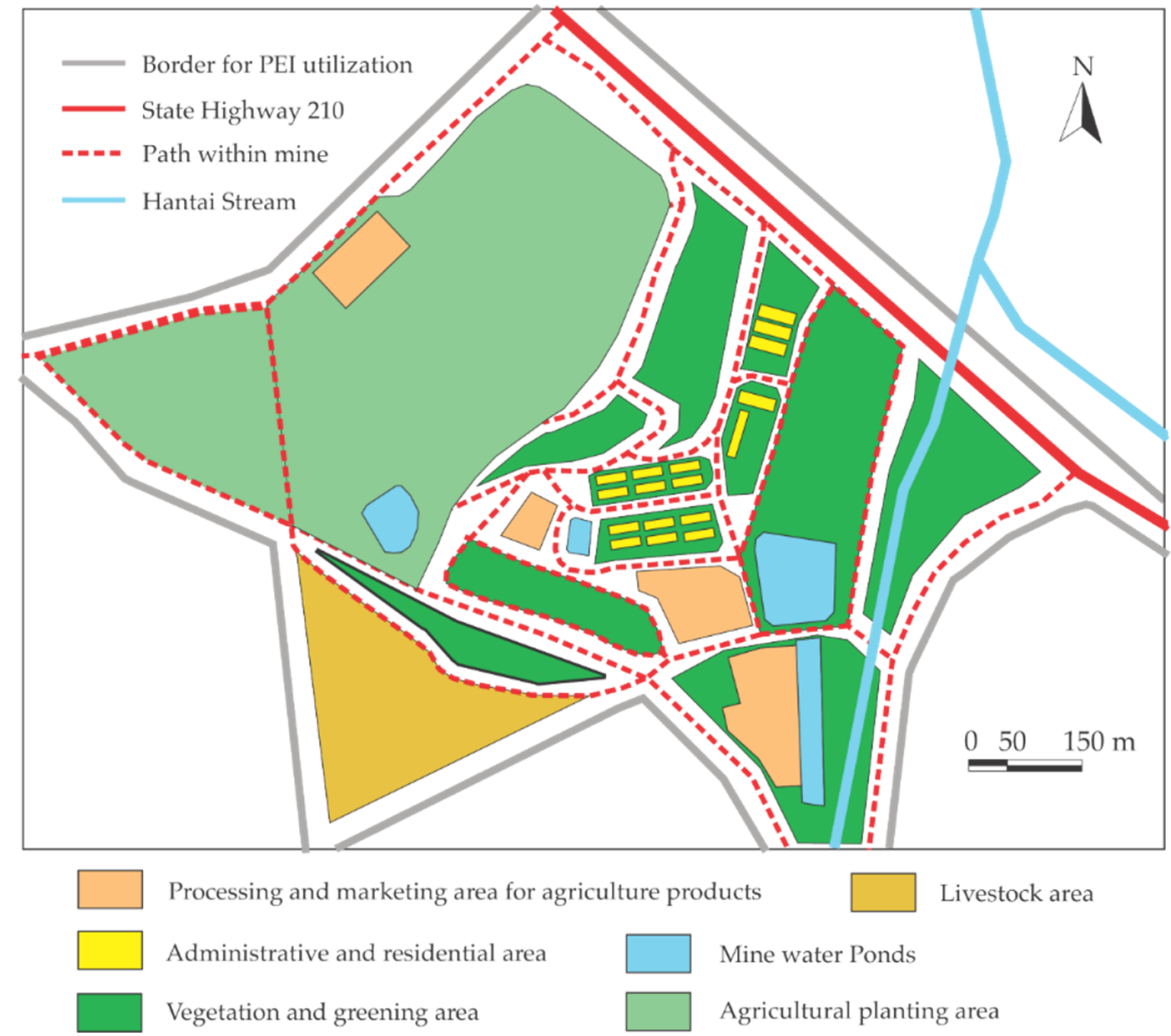

Figure 9. Post-ming land-use projects in Minda Mine.

(1) Ecosystem services: grassland, forest, and ponds

Minda coal mine is located in a hilly and ravine area, with many ditches and steep slopes, poor soil, and serious soil erosion in the original landscape. For the areas affected by the open pit and the discharge field, backfilling of the pit, leveling of the land, and greening of the grid are adopted for treatment in Minda Mine, as shown in Figure 10. A wide ridge was built around the top of the drainage field, which can be used as a road and ensure that rainwater does not flow out of the backfilled area. In the middle of the drainage field, a ridge was used to divide the land into a grid of $30 \mathrm{~m}$ in length and $50 \mathrm{~m}$ in width to ensure even infiltration of rainwater in the grid. Shrubs, perennial grasses, and more than 45,000 oil pines and 7000 populus alba var for wind and sand prevention are planted. Four ponds, with fishes, frogs, dragonflies, and birds as refuges, help to increase wildlife and enhance the local ecosystem. The vegetation greening rate of the mining backfill area reaches more than $95 \%$.

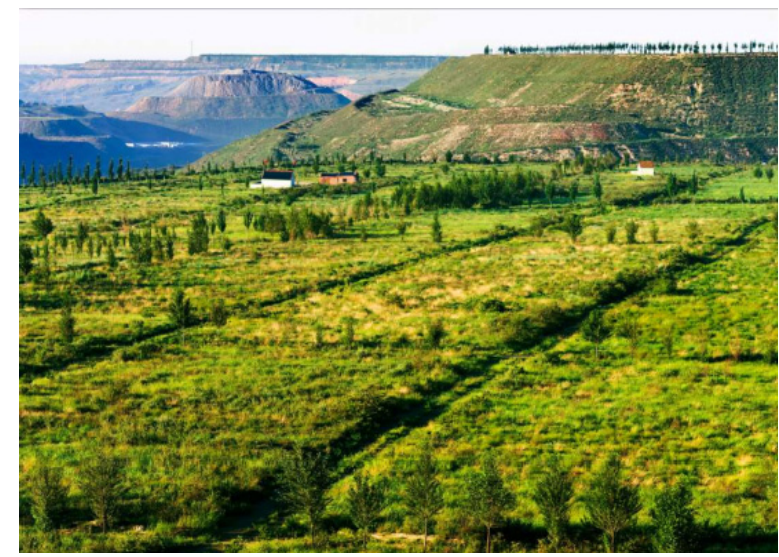

Figure 10. Ecosystem services project in Minda Mine. 
(2) Land resources: animal husbandry, crop planting, and processing factory

Minda Mine used the land restoration area, as shown in Figure A2, to build cattle sheds, pig sheds, chicken sheds, sheep pens, and fish ponds, raising 14,000 head of cattle, sheep, donkeys, and pigs, 3000 chickens, and 200,000 tails of various fish, so that the reclaimed land is reused and the ecological closed-loop cycle is formed.

Of the total 12,600 acres of planting areas, 6600 acres were planted with sea buckthorn, 3000 acres were planted with alfalfa, and 3000 acres were used as the cultivable arable land.

A factory was used to process, pack, and sell products such as vegetables, fruits, meat, eggs, fish, and dairy products. It not only makes profits for the Minda Mine but also provides job opportunities for the locals.

(3) Water resources: recycling

As Minda Mine is located in a semi-arid area, the mine has built intercepting ditches, diversion channels, rainwater recovery ponds, and drip irrigation sprinkler systems around the mining area to recycle rainwater and mine drainage as water sources for planting and to ensure the survival of vegetation. In addition, Minda Mine has invested CNY 150 million in the construction of a water storage project (Figure 11), which not only solves the pollution of surface water bodies caused by the discharge of water from the towns around the mine site but also brings 2 million cubic meters of water from the city into the mine site for irrigation every year.

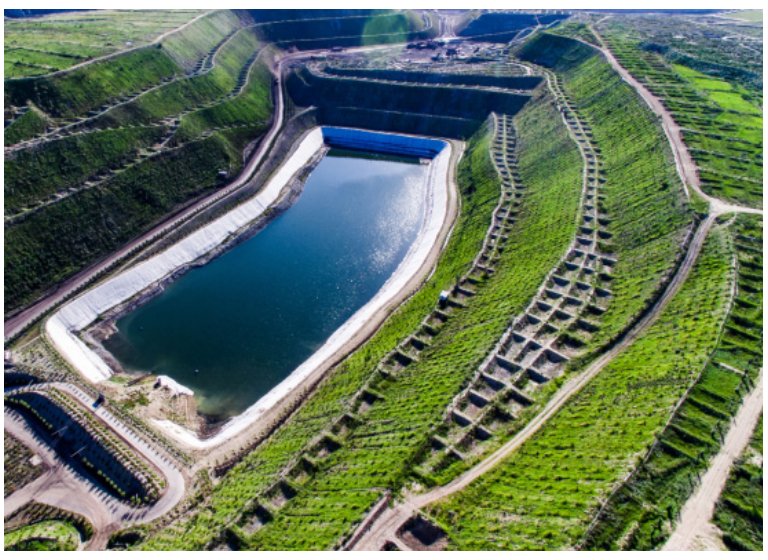

Figure 11. Water resource utilization project of Minda Mine.

(4) Underground space resource: underground storage

By using the abandoned quartz sandstone mine cave (see Figure A3), Minda Mine build an underground fruit and vegetable storage warehouse, including 3000 square meters of cold storage and 300 square meters of freezing storage for fruits, vegetables, and meat storage.

\section{Discussion}

\subsection{Multiple PEI Objectives}

Multiple PEI objectives in closed mines are preferable to be used to achieve better environmental, economic, and social effects. Correlations among different PEI objectives are established to form a closed-loop ecosystem, enlarging positive impacts on the whole. As shown in Figure 12, animal husbandry and farming benefit each other by supplying ecological feed and ecotypic fertilizer. The organic meat and organic vegetables and fruits can be stored in underground storage in mine before being sold to towns or tourists. Objectives like mining tourism, electricity for selling, and eco-products for selling are beneficial to the economy of closed mines. 


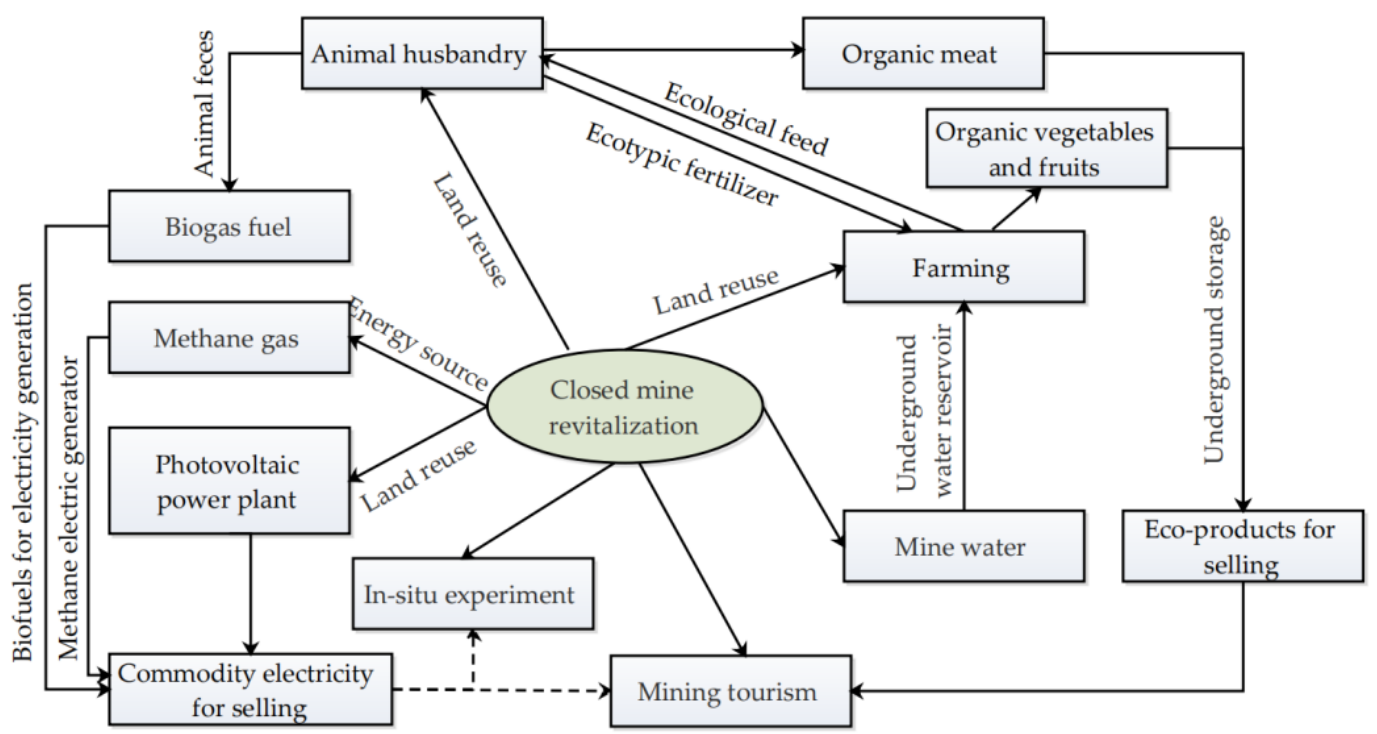

Figure 12. PEI utilization objectives system.

Thus, the utilization of PEI can act as a regional development strategy to benefit the locals economically, socially, and environmentally. If used appropriately, it can effectively improve the destroyed and fragile environment due to mining as well as address mine environmental problems. Meanwhile, it can facilitate the local economy by tourism, eco-products, commodity electricity marketing generated by PEI utilization, promoting sustainable development.

\subsection{Affecting Factors for Revitalization Objectives in Closed Mine}

PEI utilization objectives vary from site to site due to the differences in mining methods, location, morphology, aquifer characteristics, ecological vegetation, industrial and agricultural development, and so on. If a closed mine has multiple PEI objectives, quantitative comparisons should be made between different objectives to obtain the best effect, which requires a grading revitalization for different objectives. For a special closed mine, affecting factors for revitalization suitability mainly include two types, suitability factors and restrictive factors. Suitability factors are to identify the advantages and disadvantages of revitalization, while the restrictive factors are considered to recognize the opportunities or disincentives in this process. Suitability factors can be subdivided into factors such as natural conditions, mining conditions, and supplementary conditions. For example, among the factors included in natural conditions, the terrain conditions of the mine directly affect the difficulty of PEI utilization; precipitation, based on the experience of Inner Mongolia, influencing the implementation of the ecosystem service goals, especially in the mid-high latitudes in Inner Mongolia. The restrictive factors are the potential socioeconomic and environmental benefits that determine whether mine revitalization is effective.

In addition, before selecting the PEI utilization objectives in the closed mine, geological and environmental surveys conducted in mines and the surrounding area is necessary, which can help to quantify data and information, such as geological background, mining methods, present and future conditions of NEI, and other environmental information, socioeconomic status.

\subsection{Financial Support for Revitalization}

It is not feasible to close mines for direct PEI utilization. The revitalization of closing mines using PEI is based on the circular economy theory [35]. The revitalization project in closed mines is of large scale, long period, and high risk. Additionally, it involves various fields of techniques. Therefore, the local governments or mining enterprises have huge responsibilities in close mines revitalization. The private capital lacks the motivation 
to participate in these projects because of a lack of a nationwide encouraging policy in China [36]. Therefore, the Public-Private-Partnership financing model, in which the government introduces encouraging policies, closed mine enterprises provide land, plant and original production and living facilities, and private partners invest in the project, is effective in PEI development to achieve multi-interest sharing, risk sharing, and full cooperation.

\section{Conclusions}

The environmental impacts of closed mines can be divided into two types: negative environmental impacts (NEI) and positive environmental impacts (PEI). Due to drainage and ventilation being stopped in closed mines, the closure mines have caused a series of NEI on the surrounding ecological environment, such as the field variation of groundwater field and hydrochemical field. The PEI of closed mines, which are associated with NEI, are valuable resources left by closed mines that play important roles in supporting the industrial chain of mining. PEI utilization objectives of closed mines are divided into four categories: ecosystem services, cultural services, land resources and underground storage, and energy sources and mineral resources. The sub-objectives and the corresponding solutions are summarized as available schemes.

The paper studies closed mines and post-mining land uses in Inner Mongolia, which were represented by 20 typical revitalization projects. Among the 20 cases, the closed-loop ecosystem of PEI utilization in Minda Mine $\left(\mathrm{M}_{8}\right)$ was carefully studied. By achieving three objectives of PEI utilization, it sets a good example for closed mines to apply multiple PEI utilization objectives to maximize their land-using effects.

When revitalizing closed mine, a three-step framework was mentioned, which includes NEI survey and treatment, social and economic background analysis, and determination of the objectives and solutions for PEI utilization. In addition, affecting factors for optimizing the multiple objectives in closed mine revitalization are discussed.

In conclusion, by studying the closed mines in Inner Mongolia, especially the Minda Mine, the paper provides possible objectives and solutions for closed mine revitalization in other parts of the world.

Author Contributions: H.L. and Q.W. designed and directed the project; J.C., and D.Z. performed the measurements; H.L. and M.W. processed the experimental data; H.L. performed the analysis; D.Z. and C.D. contributed to sample preparation; H.L. and C.D. drafted the manuscript and designed the figures; Q.W. supervised the project. All authors discussed the results and commented on the manuscript. All authors have read and agreed to the published version of the manuscript.

Funding: Major Science and Technology Projects of Inner Mongolia Autonomous Region, China (2020ZD0020); Research project on positive impacts of typical abandoned mines in Inner Mongolia support by Natural Resources Department of Inner Mongolia Autonomous Region; Hebei Provincial Key R\&D Programme (21373901D).

Institutional Review Board Statement: Not applicable.

Informed Consent Statement: Not applicable.

Acknowledgments: This research was financially supported by the Major Science and Technology Projects of Inner Mongolia Autonomous Region, China (2020ZD0020); Research project on positive impacts of typical abandoned mines in Inner Mongolia supported by the Natural Resources Department of Inner Mongolia Autonomous Region, Hebei Provincial Key R\&D Programme (21373901D). Lastly, the authors would like to thank the editor and the reviewers for their constructive suggestions.

Conflicts of Interest: The authors declare no conflict of interest. The funders had no role in the design of the study; in the collection, analyses, or interpretation of data; in the writing of the manuscript, or in the decision to publish the results. 


\section{Appendix A}

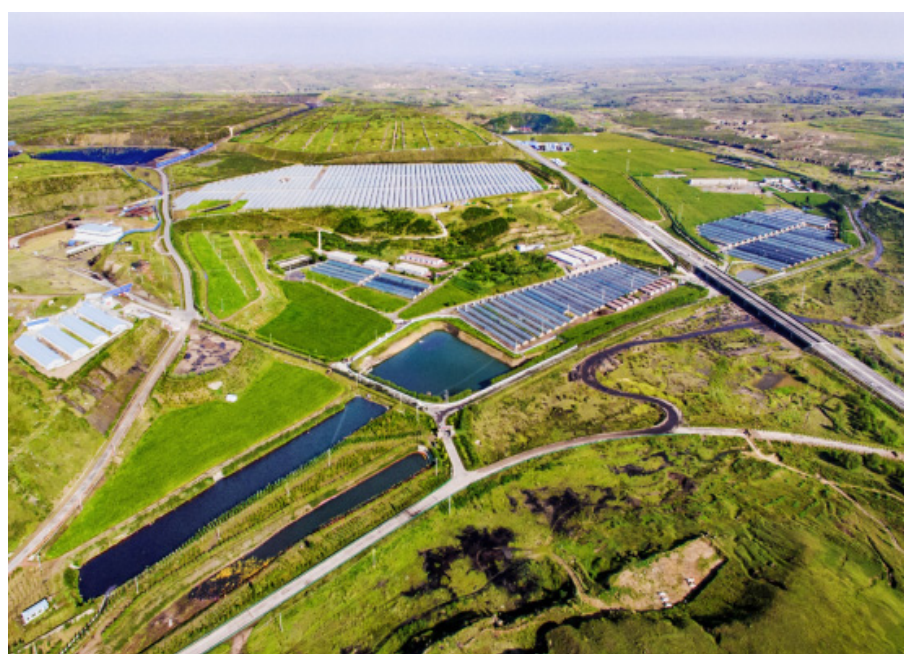

Figure A1. Aerial view of PEI projects in Minda Mine.

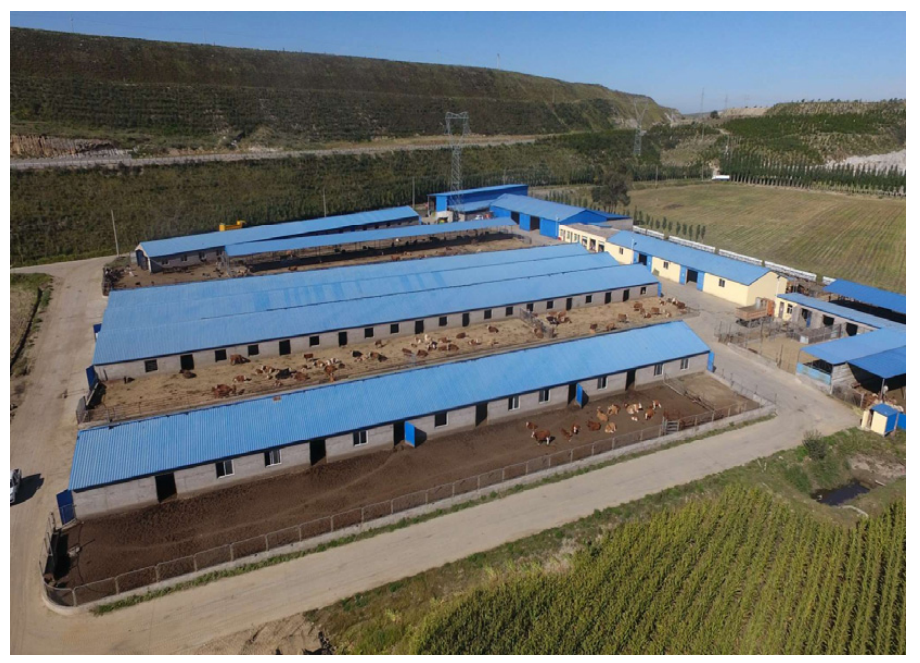

Figure A2. Animal husbandry in Minda Mine.

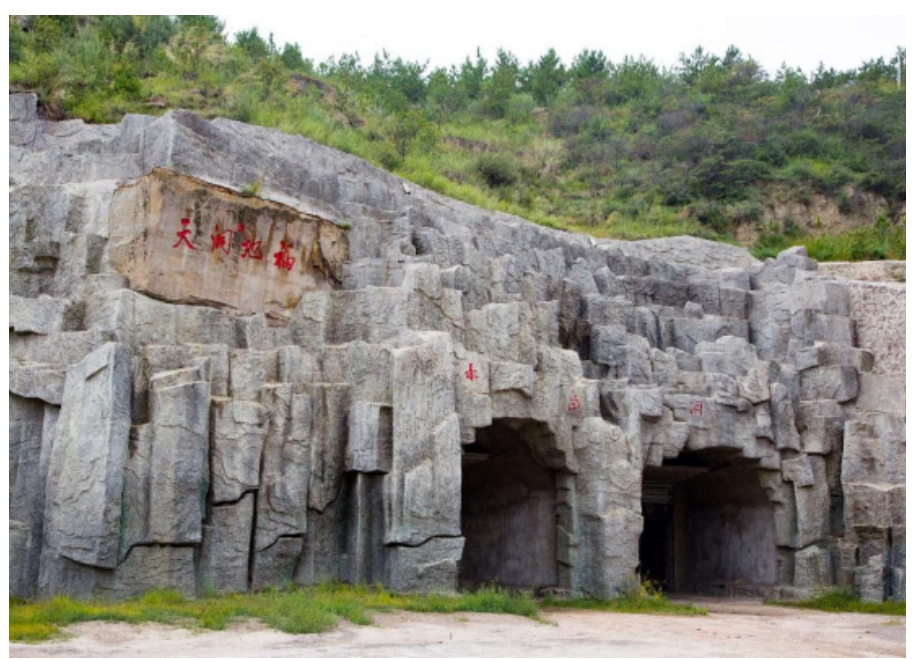

Figure A3. Mine caves for underground storage in Minda Mine. 


\section{References}

1. Morrison, W.M. China's Economic Rise: History, Trends, Challenges, and Implications for the United States; Congressional Research Service: Washington, DC, USA, 2013; pp. 20-22.

2. Naseem, S. Economies of two Asian giants India and China: A comparative study. Int. J. Bus. Soc. Sci. $2017,8,42-48$.

3. Dai, H.; Xie, X.; Xie, Y.; Liu, J.; Masui, T. Green growth: The economic impacts of large-scale renewable energy development in China. Appl. Energy 2016, 162, 435-449. [CrossRef]

4. Song, X.; Zhao, C.; Han, J.; Zhang, Q.; Liu, J.; Chi, Y. Measurement and Influencing Factors Research of the Energy and Power Efficiency in China: Based on the Supply-Side Structural Reform Perspective. Sustainability 2020, 12, 3879. [CrossRef]

5. Yuan, L.; Jiang, Y.; Wang, K.; Zhao, Y.; Hao, X.; Xu, C. Precision exploitation and utilization of closed/abandoned mine resources in China. J. China Coal Soc. 2018, 43, 14-20. [CrossRef]

6. Kivinen, S. Sustainable Post-Mining Land Use: Are Closed Metal Mines Abandoned or Re-Used Space? Sustainability 2017, 9 , 1705. [CrossRef]

7. Castrilli, J.F. Wanted: A legal regime to clean up Orphaned/Abandoned mines in Canada. McGill Int'l J. Sust. Dev. L. Pol'y 2010, 6, 109.

8. Huang, J.; Tian, C.; Xing, L.; Bian, Z.; Miao, X. Green and Sustainable Mining: Underground Coal Mine Fully Mechanized Solid Dense Stowing-Mining Method. Sustainability 2017, 9, 1418. [CrossRef]

9. Skousen, J.; Zipper, C.; Rose, A.; Ziemkiewicz, P.F.; Nairn, R.; McDonald, L.M.; Kleinmann, R.L. Review of Passive Systems for Acid Mine Drainage Treatment. Mine Water Environ. 2017, 36, 133-153. [CrossRef]

10. Naghadehi, M.Z.; Jimenez, R.; KhaloKakaie, R.; Jalali, S.-M.E. A new open-pit mine slope instability index defined using the improved rock engineering systems approach. Int. J. Rock Mech. Min. Sci. 2013, 61, 1-14. [CrossRef]

11. Ranjan, V.; Sen, P.; Kumar, D.; Singh, B. Reclamation and rehabilitation of waste dump by eco-restoration techniques at Thakurani iron ore mines in Odisha. Int. J. Min. Miner. Eng. 2016, 7, 253. [CrossRef]

12. Asr, E.T.; Kakaie, R.; Ataei, M.; Mohammadi, M.R.T. A review of studies on sustainable development in mining life cycle. J. Clean. Prod. 2019, 229, 213-231. [CrossRef]

13. Wu, Q.; Li, S. Positive and negative environmental effects of closed mines and its countermeasures. J. China Coal Soc. 2018, 43, 21-32. [CrossRef]

14. Edraki, M.; Baumgartl, T.; Manlapig, E.; Bradshaw, D.; Franks, D.; Moran, C.J. Designing mine tailings for better environmental, social and economic outcomes: A review of alternative approaches. J. Clean. Prod. 2014, 84, 411-420. [CrossRef]

15. Haddaway, N.R.; Cooke, S.J.; Lesser, P.; Macura, B.; Nilsson, A.E.; Taylor, J.J.; Raito, K. Evidence of the impacts of metal mining and the effectiveness of mining mitigation measures on social-ecological systems in Arctic and boreal regions: A systematic map protocol. Environ. Évid 2019, 8, 9. [CrossRef]

16. Bian, Z.; I Inyang, H.; Daniels, J.L.; Otto, F.; Struthers, S. Environmental issues from coal mining and their solutions. Min. Sci. Technol. 2010, 20, 215-223. [CrossRef]

17. Newman, C.; Agioutantis, Z.; Leon, G.B.J. Assessment of potential impacts to surface and subsurface water bodies due to longwall mining. Int. J. Min. Sci. Technol. 2017, 27, 57-64. [CrossRef]

18. Khan, S.; Mushtaq, S.; Hanjra, M.A.; Schaeffer, J. Estimating potential costs and gains from an aquifer storage and recovery program in Australia. Agric. Water Manag. 2008, 95, 477-488. [CrossRef]

19. Watanabe, K.; Watanabe, K.; Kodama, Y.; Syutsubo, K.; Harayama, S. Molecular Characterization of Bacterial Populations in Petroleum-Contaminated Groundwater Discharged from Underground Crude Oil Storage Cavities. Appl. Environ. Microbiol. 2000, 66, 4803-4809. [CrossRef] [PubMed]

20. Research Square: Typical Cases of Groundwater Pollution and Control Strategies for Closed Coal Mine in China. Available online: https:/ / www.researchsquare.com/article/rs-33797/v1 (accessed on 10 October 2021).

21. Bell, F.G.; Bullock, S.E.T.; Hälbich, T.F.J.; Lindsay, P. Environmental impacts associated with an abandoned mine in the Witbank Coalfield, South Africa. Int. J. Coal Geol. 2001, 45, 195-216. [CrossRef]

22. Dubiński, J. Sustainable Development of Mining Mineral Resources. J. Sustain. Min. 2013, 12, 1-6. [CrossRef]

23. Yuan, L.; Yang, K. Further discussion on the scientific problems and countermeasures in the utilization of abandoned mines. J. China Coal Soc. 2021, 46, 16-24. [CrossRef]

24. Macy, T. Comparison of Long-Term Recovery between Managed and Unmanaged Reclaimed Mine Lands. Ph.D. Thesis, Ohio University, Athens, OH, USA, 2014.

25. Baczyńska, E.; Lorenc, M.W.; Kaźmierczak, U. The Landscape Attractiveness of Abandoned Quarries. Geoheritage 2018, 10, 271-285. [CrossRef]

26. Ma, L.Q.; Zhang, D.S.; Li, X.; Fan, G.W.; Zhao, Y.F. Technology of groundwater reservoir construction in goafs of shallow coalfields. Min. Sci. Technol. 2009, 19, 730-735. [CrossRef]

27. Bukowski, P.; Wagner, J.; Witkowski, A. Use of Void Space in Abandoned Mines in the Upper Silesia Coal Basin (Poland). In Proceedings of the IMWA Symposium: Water in Mining Environments, Cagliari, Italy, 27-31 May 2007; pp. 147-151.

28. Liu, H.L. Research on the Theory and Practice of the Restoration and Utilization Model for the Mine Environment. Ph.D. Thesis, China University of Mining and Technology (Beijing), Beijing, China, 2020.

29. Loredo, J.; Ordóñez, A.; Jardón, S.; Álvarez, R. Mine water as geothermal resource in Asturian coal mining basins (NW Spain). In Proceedings of the IMWA Congress, Aachen, Germany, 4-11 September 2011; pp. 177-181. 
30. Bazargan, B.; Demollin, E.; Van Bergermeer, J.J. Geothermal Use of Deep Flooded Mines. In Proceedings of the Conference Post-Mining, Nancy, France, 6-8 February 2008; pp. 1-10.

31. Ramos, E.P.; Breede, K.; Falcone, G. Geothermal heat recovery from abandoned mines: A systematic review of projects implemented worldwide and a methodology for screening new projects. Environ. Earth Sci. 2015, 73, 6783-6795. [CrossRef]

32. Jun, D.; Pei, W.; Ainiwaer, P.; Shilin, N. Research on Time-of-use Electricity Price Model Based on Hierarchical Clustering-Price Elasticity Theory. Am. J. Electr. Power Energy Syst. 2019, 8, 95. [CrossRef]

33. Pujades, E.; Willems, T.; Bodeux, S.; Orban, P.; Dassargues, A. Underground pumped storage hydroelectricity using abandoned works (deep mines or open pits) and the impact on groundwater flow. Hydrogeol. J. 2016, 24, 1531-1546. [CrossRef]

34. Chen, J.X.; Liu, X. Closed mines survey results in Inner Mongelia. In Survey Report on the Geological Environment of Closed Mines (Closed Pits, Policy Closures, and Abandoned Mines) in Inner Mongolia, 1st ed.; Geological Environment Monitoring Institute of Inner Mongolia Autonomous Region: Hohhot, China, 2019; pp. 14-25.

35. Segura-Salazar, J.; Tavares, L.M. Sustainability in the Minerals Industry: Seeking a Consensus on Its Meaning. Sustainability 2018, 10, 1429. [CrossRef]

36. Gilligan, J.; Wright, M. Private Equity Demystified: An Explanatory Guide; Oxford University Press: Oxford, UK, 2020. 